\title{
High-rise construction in the Saint Petersburg agglomeration in 1703-1950s
}

\author{
Sergey Sementsov ${ }^{1 *}$, Nadezhda Akulova ${ }^{1}$, and Severina Kurakina ${ }^{1}$ \\ ${ }^{1}$ Saint Petersburg State University of Architecture and Civil Engineering, Department of Architectural \\ and Urban-Planning Heritage, 4 Vtoraya Krasnoarmeyskaya str., Saint Petersburg, Russian Federation
}

\begin{abstract}
Regularities of high-rise construction (implemented projects and developments) in Saint Petersburg and the Saint Petersburg agglomeration since the foundation of the city in 1703 till the 1950s are considered. Based on these regularities, a single spatially developed system of vertical dominants is formed. High-rise construction in the city and its suburbs started in the 1710s and continues up to the present time. In the considered decades (1703-1950s), high-rise construction mostly performed urbanplanning functions (with vertical and symbolic dominants), relying on patterns of the visual perception of man-made landscapes under development. Since the 1710 s, the construction of vertical dominants (mainly temples, spires of towers, lighthouses, etc.) of five ranks (depending on the altitude range and in relation to the background development) was conducted in territories of the entire agglomeration. These dominants were arranged in landscapes of the city and suburbs with almost mathematically precise accuracy and according to special regulations. Such dominants obtained particular descriptive and silhouette characteristics in accordance with the conditions of spatial perception. In some periods of city development, attempts were made to create monuments (symbolic dominants) of specific height and include those in the spatial system of highrise dominants as significant elements of the city silhouette.
\end{abstract}

\section{Introduction}

Several stages in the creation of the system of high-rise facilities can be distinguished with regard to Saint Petersburg and its agglomeration. Even during the development of the flat, swampy landscape, where the Saint Petersburg agglomeration consistently formed since 1703 , numerous waves in the creation of the system of high-rise facilities can be traced. Revealing regularities in the spatial construction of such high-rise facilities is one of the tasks of historical and urban-planning studies regarding Saint Petersburg.

\section{Methods}

\footnotetext{
${ }^{1}$ Corresponding author: s.sementsov@mail.ru
} 
Concurrent comprehensive studies of vast arrays of urban-planning and architectural archive materials, comparative full-scale studies of survived and/or lost facilities.

\section{Results}

High-rise construction in territories of the Neva plain, whereon the capital city of Saint Petersburg and surrounding suburban flat lands formed since 1703, started since the 1710s, according to personal orders of Peter the Great [Figure 1].

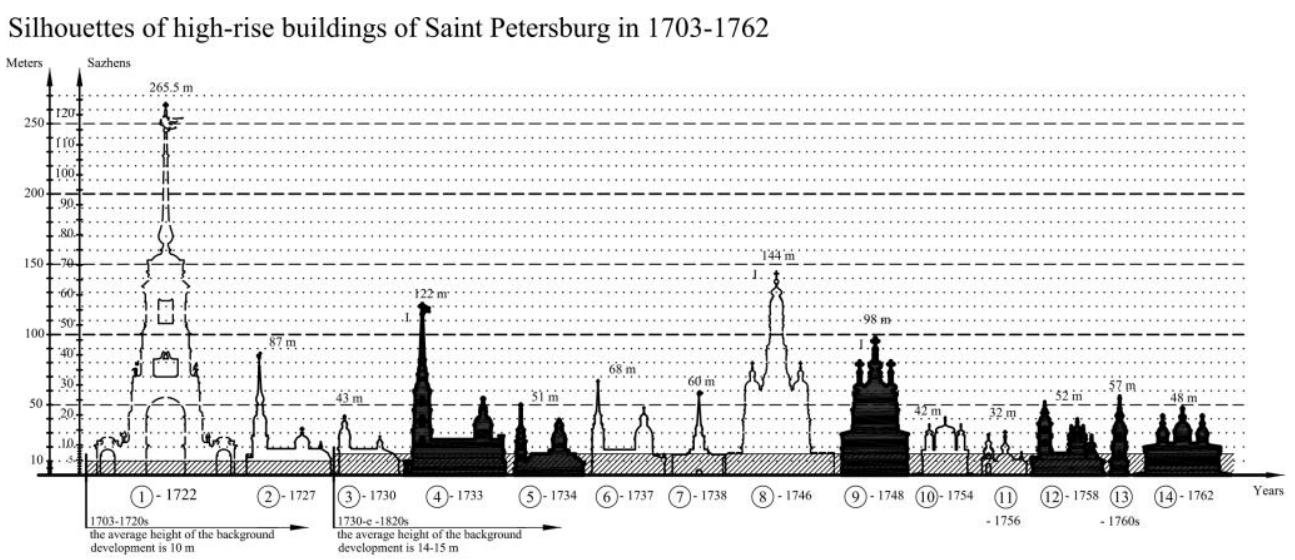

Silhouettes of high-rise buildings of Saint Petersburg in 1763-1849

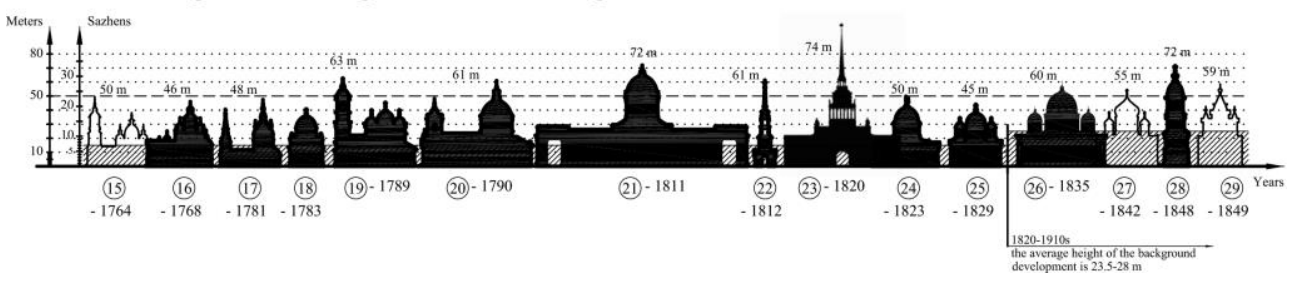

Fig. 1. Construction of vertical dominants in Saint Petersburg in 1703-1850s

Up until the middle of the 1720s, highest buildings were erected not only in the city, but also in its suburbs according to his initiatives: the Peter and Paul Cathedral (with the bell tower, the spire of which reached the height of $122 \mathrm{~m}$, No. 4 on schemes), the original building of the Admiralty Shipyard (with the spire of $40 \mathrm{~m}$ in height), as well as few buildings with spires of lower height. As is obvious, these were not only temple buildings, but also public and industrial buildings (Foundry Yard (Liteiny Dvor), Particular Shipyard, lighthouses at the western end of Vasilyevsky Island, etc.). In the years of 1721-1723, the construction of a high-rise lighthouse (with the design spire height of $266 \mathrm{~m}$, No. 1 on schemes), which contemporaries compared with the ancient Colossus of Rhodes (which was "only" $37-40 \mathrm{~m}$ in height), was started by the main ship channel to the south of Kronstadt (however, it was not completed). This height was predetermined in decrees as a necessary condition (and a requirement) for creating high-rise compositional dominants on axes of main streets (roads, main lines) of urban and suburban territories and main ship channels in the waters of the Gulf of Finland, as main dominants for the visual arrangement of formed urban and suburban spaces [1]. 
Silhouettes of high-rise buildings of Saint Petersburg in 1850-1920

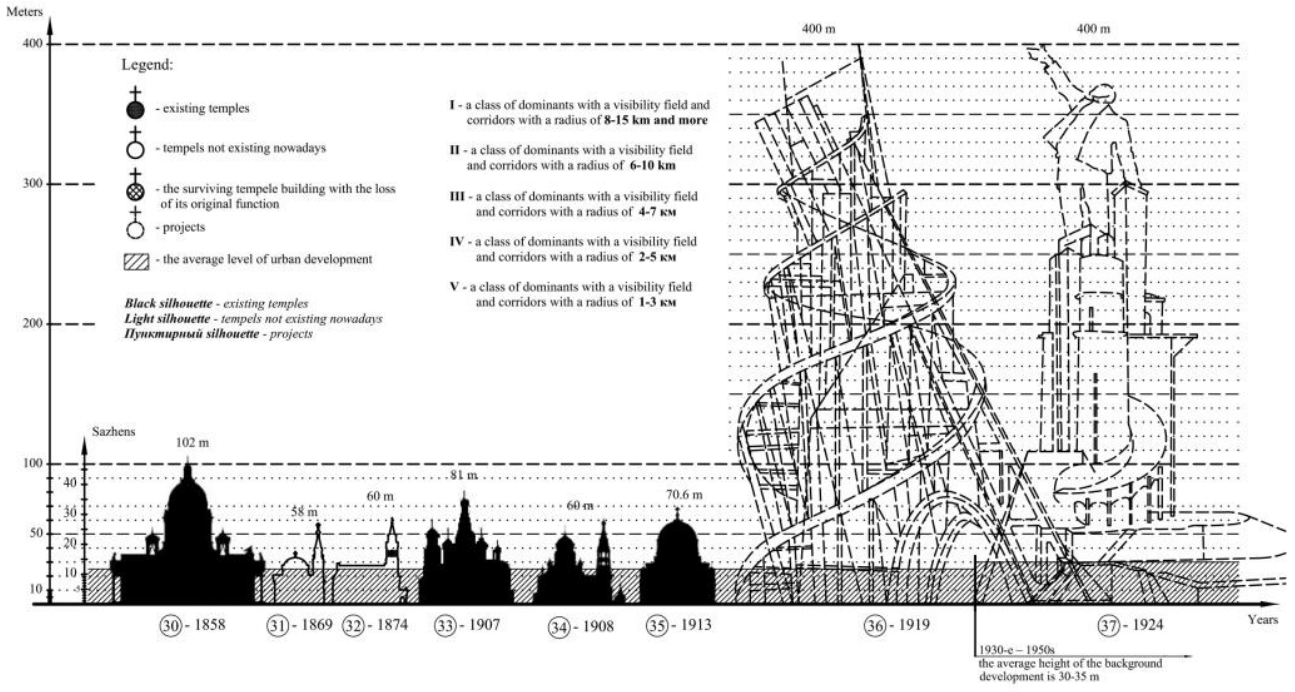

Fig. 2. Construction of vertical dominants in Saint Petersburg - Petrograd in 1851-1924

At the same time, the formation of the system of symbolic dominants was conducted in the territories of the city and suburbs. Their creation was carried out according to another principles and did not always take into account patterns of vertical perception and requirements for the altitude of facilities, remaining often within the framework of the symbolic field "only". For example, among main symbolic dominants of Petrine times not only main vertical dominants (e.g. the Peter and Paul Cathedral), but also less higher objects (but with equally powerful symbolic aura) (e.g. the original Trinity Cathedral on Troitskaya Square, the height of which did not exceed $15 \mathrm{~m}$ ) were distinguished. In terms of the structure, such constructions were erected with brick walls, with the use of a log-frame system of high spires and domes, with pile wooden foundations. And as for the first erected buildings, the use of log-crib constructions in foundations can be noted [2].

Silhouettes of high-rise buildings of Saint Petersburg in 1921-1950s

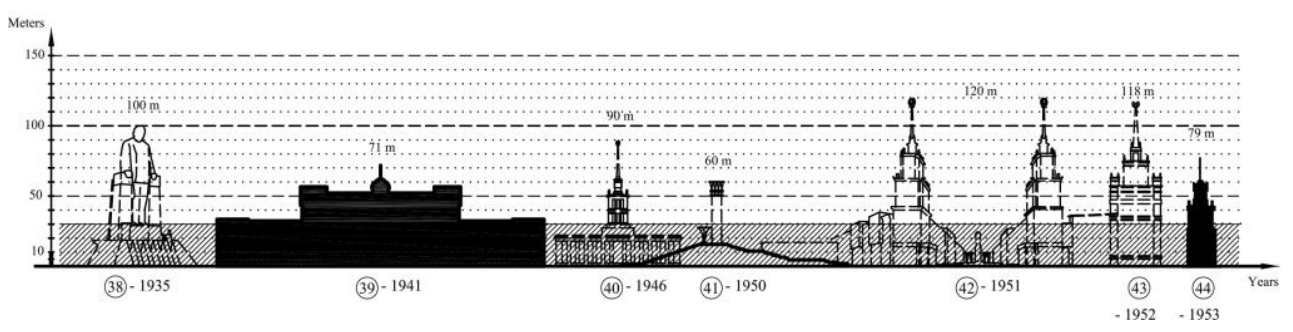

Fig. 3. Construction of vertical dominants in Leningrad in 1925-1950s.

Thus, as early as in those decades, high-rise construction started ("high-rise" in terms of Saint Petersburg conditions) as the system of relatively small vertical and symbolic dominants rising above the standard "background" development to various extents.

Later, under the reign of Anna Ioannovna, in the 1730s, temples and objects of civil and industrial architecture of lower height (with spires of only up to 30-40 m in height) were mainly erected as dominants in the city and suburbs. However, the Admiralty Shipyard was reconstructed and the height of its timber spire increased up to $60 \mathrm{~m}$ (No. 7), becoming one 
of the largest verticals. Under the reign of Elizaveta Petrovna during 1740-1750s, the group of the highest objects of the city and its suburbs (in the framework of the single Saint Petersburg agglomeration) was supplemented by the Smolny Cathedral of the Resurrection (height of the cross over the central dome - $98 \mathrm{~m}$, No. 9) and the bell tower, the construction of which was started but not completed (height of the hipped spire - $144 \mathrm{~m}$, No. 8) [3].

Until the end of the $18^{\text {th }}$ century, the large-scale vertical construction in the city and suburbs was performed with objects of relatively low height. The majority of temples and industrial objects built in those decades, with overall dimensions of vertical elements not exceeding 30-40-50 m, had fairly average height by standards of the time.

By the beginning of the $19^{\text {th }}$ century, the mathematically precise and spatially accurate system of vertical dominants formed in the city, which is clearly seen on the famous Vitztum plan (1821) [Figure 4]. Not only temples themselves (with domes and bell towers), but domes of civil buildings, the highest tops (attics), other elements of development, vertical in terms of semantics and morphology, served as visual vertical dominants [4]. This direction of mathematically precise arrangement of high-rise dominants in the spatial system of the entire city not only continued up to 1917 , but also preserved traditions till the 1950 s.

Throughout the whole $19^{\text {th }}$ century, objects of vertical construction included numerous temples, keeping the overall height within 50-60 m. They also included several largest and, at the same time, highest buildings, i.e. the Kazan Cathedral (built in 1801-1811, $72 \mathrm{~m}$ high, No. 21) and Saint Isaac's Cathedral (erected in the 1830's-1850's, with the height up to the cross top of $102 \mathrm{~m}$, No. 30). These objects also became new main symbolic dominants of the Russian capital. At the beginning of the $20^{\text {th }}$ century, the Naval Cathedral (with the height up to the cross top of $71 \mathrm{~m}$, No. 35) was erected on Kotlin island in the center of Kronstadt, 35 $\mathrm{km}$ from the city, which officially became the main naval cathedral in Russia $[5,6]$.

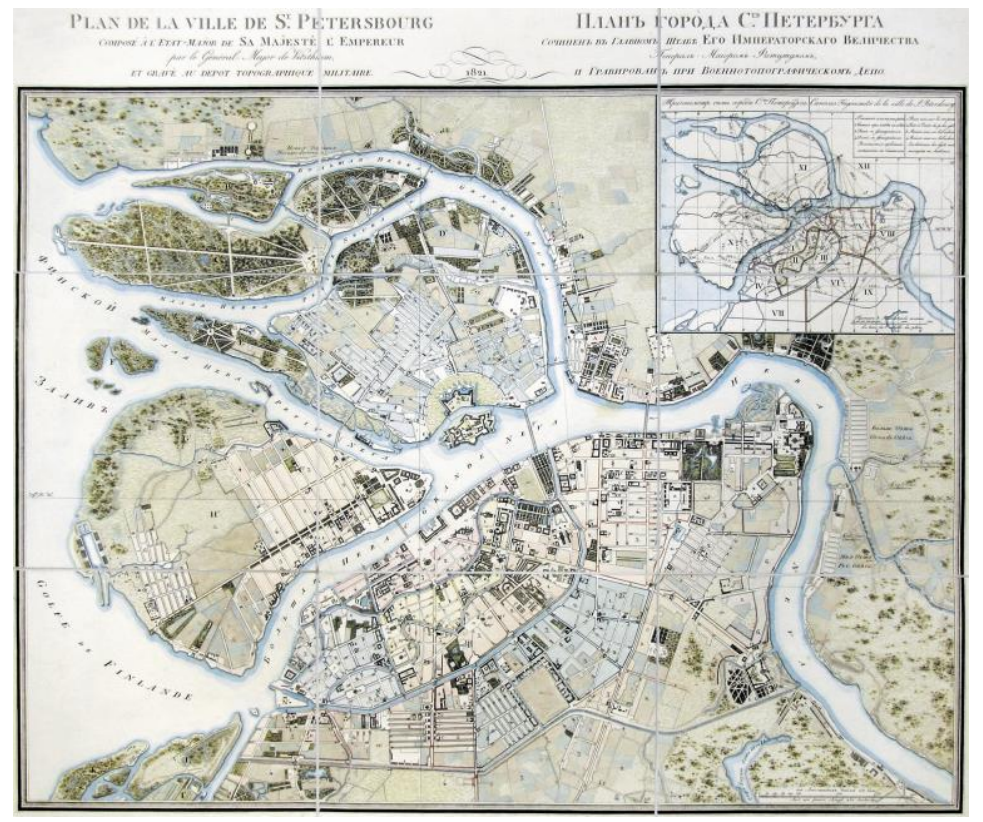

Fig. 4. PLAN OF THE CITY OF SAINT PETERSBURG compiled in the General Headquarters of HIS IMPERIAL MAJESTY by Major General I. Vitztum AND ENGRAVED IN THE MILITARY TOPOGRAPHICAL DEPOT. 1821 / PLAN DE LA VILLE DE St. PETERSBOURG Composé à l'Etat-Maior de SA MAJESTÈ L' EMPEREUR par le Général-Major de Vitzthum, ET GRAVÈ AU DEPOT TOPOGRAPHIQUE MILITAIRE. 1821. Saint Petersburg. RNb K1-Pb 6/72. 
By the beginning of the $20^{\text {th }}$ century, construction on Saint Petersburg soils and under Saint Petersburg natural and climatic conditions led to the use of not only brick walls and vault structures, but also monolithic concrete and reinforced concrete frames and loadbearing brick walls. Foundations were based on solid wooden pile fields (of larch and oak).

Such large-scale development of territories led to the fact that even suburban territories were densely developed with vertical dominants which were erected in centers of settlements, at crossroads and in road bends, in elevated areas, in visual centers between settlements, i.e. in centers of spatial perception of man-made and natural landscapes. Plain natural and manmade landscapes of suburban districts (uyezds) (e.g. Tsarskoye Selo district (uyezd)) allowed erecting temples (as vertical and symbolic dominants) of 40-50-60 m in height. The location of these dominants in the district territories was quite precise in terms of spatial arrangement. It is clearly seen in the map of the Tsarskoye Selo district (uyezd) (as of 1916). It shall also be note that the spatial arrangement of temples in Saint Petersburg, in suburban districts (uyezds) (through the example of the Tsarskoye Selo district (uyezd)) and in the territories of the Saint Petersburg governorate (guberniya) (as a whole) was carried out according to unified principles and patterns [7].

At the beginning of the $20^{\text {th }}$ century (after 1917), during the first stage of socialist state formation and the spread of "avant-garde" ideas, a wave of proposals to create the largest world-class revolutionary monuments emerged. The powerful burst of symbolic energy led to the fact that, during the first years under the Soviet power, unusual grand projects (in terms of spatial design) with eclectic symbols were developed and proposed for construction [8]. Those projects included proposals for erecting the Tower to the Third International (Tatlin's Tower with the height of 400 m, No. 36) on Troitskaya Square in Petrograd in 1919 (author - architect and designer V. Ye. Tatlin) and the monument to V. I. Lenin, proposed by architect V. A. Shchuko (with the height of $400 \mathrm{~m}$, No. 37), in the same place in the beginning of 1924 [9, 10, 11] [Figure 2].

Even projects of applied technical facilities of those times were distinguished by gigantic sizes. For example, during the contest for the construction of a lighthouse in the Sea Port of Leningrad, a lighthouse in the form of a sculpture of V. I. Lenin (100 m high, No. 38) was proposed [12]. It was proposed to build those objects in bearing structures of the metal and reinforced concrete frame, but with foundations based on solid wooden pile fields (of larch and oak).

In the 1930s-1950s, within the framework of developed master plans for the formation of the new, socialist Leningrad, proposals for erecting tens of high-rise buildings, which were to form the system of high-rise dominants in the single silhouette field of the entire city, primarily within the borders of the new, socialist Leningrad, were made. Projects for the arrangement of dominants (of various functions: public, residential, and industrial) were developed, their urban-planning significance and altitude range (in relation to the significance and altitude range of other dominants) were determined. It could be clearly seen in design documents for the urban planning of Leningrad main lines (Moskovsky prospect, Stachek prospect, Zanevsky prospect, Kirovsky prospect, etc.), main entrances to Leningrad. Among those, projects of the House of Soviets (spire height - 71 m, No. 39), Finland Railway Station (spire height $-90 \mathrm{~m}$, No. 40), residential buildings on the routes along Neva embankments, public buildings can be noted [13].

Not many of numerous projects for the creation of vertical dominants were implemented. Among outstanding examples of this project-based approach, numerous options for the reconstruction of Moskovsky prospect (Stalin prospect at the time) with proposals for the polyrhythmic arrangement of stand-alone dominants (with height of up to 110-120 m, Nos. 42,43 ) and dominants, integrated in the system of residential buildings (with height of up to $70-80 \mathrm{~m}$, No. 44), can be noted [14, 15, 16] [Figure 3]. 
The altitude range of all these buildings was not random. It corresponded to the requirements for the implementation of spatial visibility and symbolic perception tasks, as well as possibilities of building construction on Saint Petersburg - Leningrad swampy soils, ensuring the erection of vertical and symbolic dominants. It was possible to perform such tasks by creating buildings of special type rising above the standard "background" development to various extents.

"Standards" of the altitude range of the Saint Petersburg background development were changed several times according to imperial decrees and officially approved urban-planning requirements. The average height of the background development depended on the formation period and created a plain silhouette for the main part of urban and suburban development. For example, in the 1703-1720s, the average height of the background development (taking into account the height of roofing to the ridge top) was about $10.0 \mathrm{~m}$ (one floor, high basement, high roofing). In the $1730 \mathrm{~s}-1820 \mathrm{~s}$, the average height of the background development was approximately $14-15 \mathrm{~m}$ ( 2 floors, high basement, high roofing). In the $1820 \mathrm{~s}-1910 \mathrm{~s}$, it was $23.5-28.0 \mathrm{~m}$ (5-6-story buildings with the roofing at an angle of 18 $30^{\circ}$, or with attics, which provided the height of the ridge top at the same level), in the 1930s1950s, it was 30-35 m (5-7-story buildings, high basement, with the roofing at an angle not exceeding $30^{\circ}$ ).

With the beginning of the era of industrial housing construction and wide use of industrial methods of construction, the number of floors (altitude range) of the large-scale standard background development began to increase rapidly in the city. In the 1950s-1960s, the altitude range of the background development was 16-17 $\mathrm{m}$ (5 floors of industrial buildings of the first large-scale prefabricated housing, low basements, flat roofing), in the 1970s1980 s, the altitude range of the standard background development was already 37-38 m (912 floors with flat roofing), and in the 1990s it rapidly and significantly increased and reached 72-75 m (24-25 floors with flat roofing).

The absolute size and height of vertical dominants in comparison with the background development played a big role, predetermining their altitude and visual significance, as well as the spatial and compositional role. As early as in Petrine times, in territories of Saint Petersburg formation and development of suburban areas, i.e. in the zone of the development of flat landscapes, deliberate formation of a system of vertical dominants, designed for various zones of perception and spatial arrangement, started. Different absolute heights, different "excess" over the background development, and, at the same time, different characteristics of "visual work" in the area being formed were stipulated (by design solutions and construction capabilities) for various elements of the system of high-rise dominants. Absolute dimensions (absolute height) made it possible to provide the visibility of objects from different distances. The relative altitude range (relative to the background development) also helped to ensure contrast (nuances) in the perception of dominants, their visual orientation features.

Class (rank) 1. Dominants of regional significance. The designed and implemented height of objects reached $100 \mathrm{~m}$ and more. Facilities of such height were constructed throughout the entire development of the city. This group includes: the lighthouse by the Kronstadt canal (1721-1723, the construction was not completed, height $-265 \mathrm{~m}$, No. 1 on schemes); the Peter and Paul Cathedral (the construction was completed in 1733, spire height of the bell tower - 122 m, No. 4); the Smolny Cathedral of the Resurrection (built in 1748, height of the main dome $-98 \mathrm{~m}$, No. 9) and the unfinished bell tower of the Smolny Monastery (design height - 144 m, No. 8); the Saint Isaac's Cathedral (built in 1858, height of the cross over the dome - $102 \mathrm{~m}$, No. 30).

A few more objects were slightly lower, but due to special architectural solutions (sharp silhouette, gilding, etc.) they can also be referred to the group of major dominants of the historic city. Among such objects: the Kazan Cathedral (with the dome top at the height of 
72 m, No. 21); the spire of the Main Building of the Admiralty (with the spire top at the height of $74 \mathrm{~m}$, No. 23); the Bell Tower of the Vladimirskiy Cathedral on Vladimirskaya square (72 m high, No. 28); the Church of the Savior on Blood (81 m high, No. 33); the Naval Cathedral of St. Nicholas the Wonderworker in Kronstadt (71 m high, No. 35).

In terms of height, the first group of objects is in large excess over the background development: during the construction of high-rise objects, their height was 7-10 times more than the height of the background development. And in the next decades (up to the end of the $20^{\text {th }}$ century), upon the stable preservation of the altitude range with regard to the background development of the historical center of the city at the level of 24-30 m, it was 4-6 fold higher. The second group was initially $2-4$-fold higher than the background development, and at the beginning of the $20^{\text {th }}$ century it was $2-3$-fold higher.

The main high-rise dominants (dominants of the first group) provided spatial perception (and visual arrangement) at distances of up to $30 \mathrm{~km}$ and more, and dominants of the second group - at distances of up to $8-15 \mathrm{~km}$.

Class (rank) 2. Dominants of city significance. With the height of domes and spires in the range of 50-60 m. They were erected both in the city and in extensive suburban territories, especially in the zones of main lines and routes, within the borders of the entire historical Saint Petersburg agglomeration. Among them: the Church of the Holy Righteous Simeon and Anna the Prophetess (height of the bell tower spire - $51 \mathrm{~m}$, No. 5); the St. Nicholas Naval Cathedral (height of the central dome - $48 \mathrm{~m}$, No. 14) and the stand-alone bell tower (height - 57 m, No. 13); the Church of the Vladimir Icon of the Mother of God (height of the central dome - 47 m, No. 16); the Holy Trinity Cathedral in the Alexander Nevsky Lavra (height of the cross above the main dome $-62 \mathrm{~m}$, No. 20), the bell tower of the Cathedral of the Exaltation of the Holy Cross (spire height - $61 \mathrm{~m}$, No. 22). During construction, they were 3-4-fold higher than the background development, and when the height of the background development increased up to 24-30 m, they were 2-2.5-fold higher. Such altitude characteristics of buildings and their prominence relative to the background development provided visual arrangement of spaces with a radius of $6-10 \mathrm{~km}$.

Class (rank) 3. Dominants of district significance. With the height of domes and spires in the range of $40-50 \mathrm{~m}$. Such buildings and groups of buildings were widely spread. The designed and implemented height of objects 2.5-3-fold exceeded the average height of the standard (background) surrounding development (in decades before the 1820s) and 2-fold exceeded the average height up to 1917, providing visual arrangement of spaces with a radius of $4-7 \mathrm{~km}$.

Class (rank) 4. Dominants of local significance. Such dominants also represent one of the most common options of historical "high-rise development"; at the stage of the development of the historical Saint Petersburg with the height of the background development of $15 \mathrm{~m}$ (in 1703-1820s), such "dominants" had a height of 25-35 m, and when the background development exceeded $24 \mathrm{~m}$ (in the 1820-1910s), such dominants had a height of up to 40$45 \mathrm{~m}$. Thus, even such height 1.5-2-fold exceeded the height of the background development. With regard to plain areas of the suburban zone with local rural settlements (and the average height of buildings of 10-15 m), they certainly represented dominants, providing spatial and orientational distinctions of the perception environment. Thus, such dominants were also well perceived in the visual field, providing visual arrangement of spaces with a radius of $2-5 \mathrm{~km}$.

Dominants of classes (ranks) 3 and 4 were of the largest scale in the city's development and in the development of the suburban zone landscapes (agglomeration territories). In the city, they prevailed mainly in the first half of the $18^{\text {th }}$ century, and in vast territories of the Saint Petersburg governorate (guberniya) they were the most widespread until the beginning of the $20^{\text {th }}$ century. This can be clearly seen through the example of the entire Saint Petersburg governorate (guberniya) (on a scheme demonstrating its state as of 1850) [Figure 5] and, in 
particular, the "exemplary" (as it was indicated in documents of those years) suburban Tsarskoye Selo district (uyezd) (on a scheme demonstrating its state as of 1916) [Figure 6].

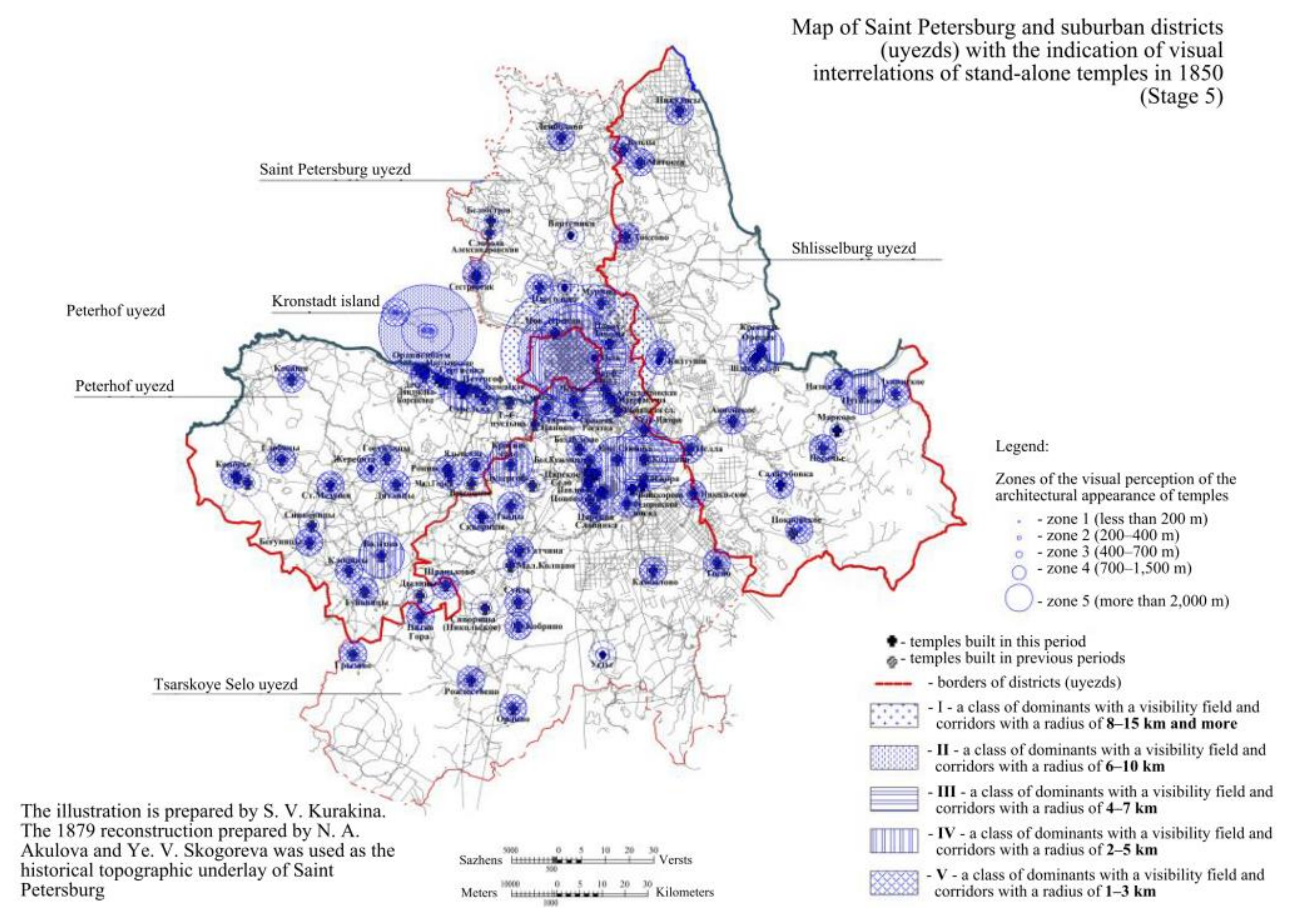

Fig. 5. Map of Saint Petersburg and suburban districts with the indication of the arrangement of temples and their visibility zones (as of 1850).

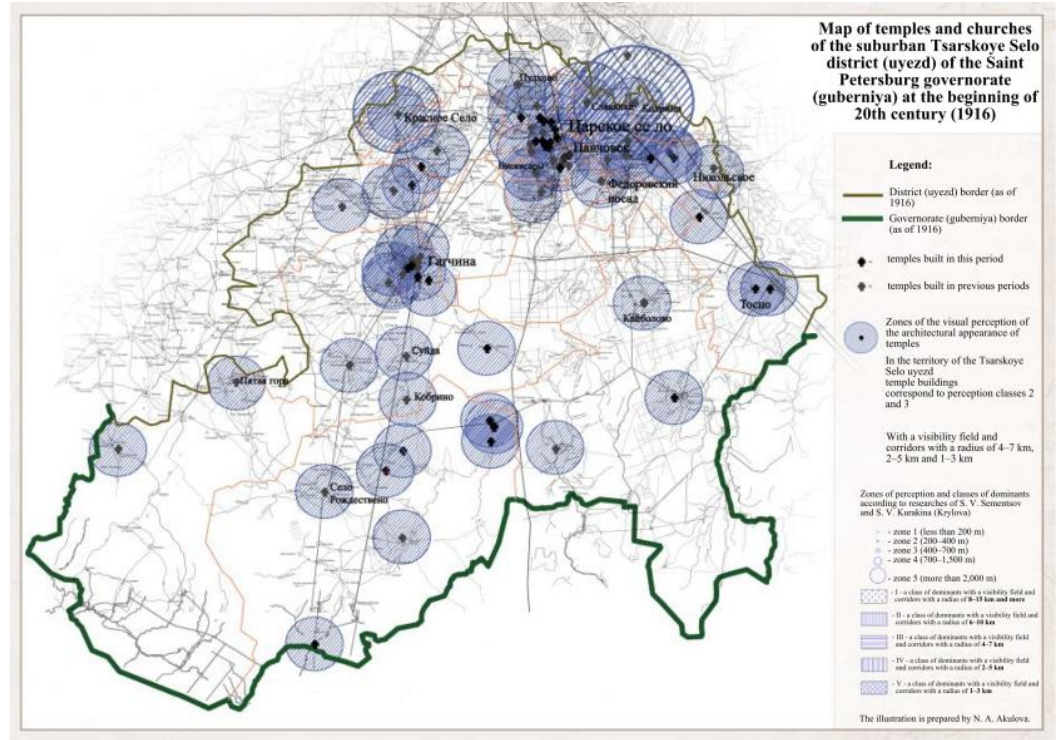

Fig. 6. Map of suburban Tsarskoye Selo district (uyezd) with the indication of the arrangement of temples and their visibility zones (as of 1916) 
Such high-altitude arrangement of suburban temples provided the spatial development of visual fields of plain spaces in the governorate [17]. Text: "On the 2nd day of this September, the Emperor, according to the regulation of the Minister of Internal Affairs, commands to: for the lifetime of the Governorate Committee, established by His Majesty on May 15, 1845 to handle common affairs concerning the exemplary arrangement of the Saint Petersburg and Tsarskoye Selo districts (uyezds), appoint a special official for documentation management in such committee, with position of grade 9 , and with grade 9 as for the uniform and pension, with a scribe to assist; the remuneration shall be allocated from the local tax of the Saint Petersburg governorate in the amount of 200 rubles for salary and 143 rubles for accommodation (for the special official), in total: 343 rubles, and 173 rubles in silver per year for the scribe" [17]. "On the appointment of a special official for documentation management in the Governorate Committee established to handle affairs concerning the arrangement of the Saint Petersburg and Tsarskoye Selo districts (uyezds)".

Class (rank) 5. Local dominants. Dominants in the form of towers, spires, domes, etc., which had a height of 2-5-8 $\mathrm{m}$ above the level of eaves in historical buildings. They were widely spread in the urban development and in suburban towns in the middle and end of the $19^{\text {th }}$ century. The designed and implemented height of objects only 1.1-1.2-fold exceeded the height of the background development, reaching 20-22.0 $\mathrm{m}$ in the $18^{\text {th }}$ century, and $30-35 \mathrm{~m}$ - by the end of the $19^{\text {th }}$ century, providing visual arrangement of spaces with a radius of $1-$ $3 \mathrm{~km}[18,19,20]$.

In general, this multi-level system of vertical dominants had significant features of vertical construction. However, only designed (unrealized) and erected objects of class (rank) 1 with a height of 70-100 m and more can be classified as high-rise buildings. What features of the system were the most "in-demand" during the creation and functioning of the city and its suburbs? Probably, both features in their unity and inseparability.

This spatial high-altitude system formed in the course of the entire development of Saint Petersburg and the Saint Petersburg agglomeration, emerging gradually, step by step.

Chronologically, such five-level system of vertical visual and symbolic dominants, including real high-rise objects, began to form as early as in the first decades of the foundation of Saint Petersburg, under the reign of Peter the Great. As far back as at that time, objects of classes (ranks) 1-5 were created. Initially, under the reign of Peter the Great, the system of vertical dominants of all five ranks almost immediately and systematically started to form, ensuring the network multi-layer development of formed spaces. However, at that time the large-scale development had a height of only 1-2 floors (4.5-10.0 m taking into account the height up to the roof ridge). Even palaces of the nobility were not higher than 10.0-12.0 $\mathrm{m}$ (according to the height of the roof ridge) in Petrine times. Therefore, all dominants of various ranks rising above them represented very important visual references under conditions of flat terrains of the Prinevskaya Plain. Efforts to erect objects with a height of 122-266 m were, obviously, predetermined by the need to solve more complicated tasks than those related to the provision of the visibility of developed spaces.

\section{Conclusions}

Until the 1950s, in territories of Saint Petersburg - Leningrad and its extensive agglomeration, a single tradition of creating the system of vertical dominants formed (mainly by the historical system of temples and vertical spires, etc.), which, in its turn, was based on common principles of the visibility and formation of visual zones (visibility zones) and visibility axes, and resulted from the system of five classes (ranks). Among those, objects of class (rank) 1 were $70-120 \mathrm{~m}$ high or more and actually represented historical high-rise objects, i.e. dominants having an orientational and/or symbolic component. They formed in a single spatial field of the city-governorate. In the history of the urban-planning 
development of Saint Petersburg, periods when large-scale proposals were formulated to erect super-high buildings $260-400 \mathrm{~m}$ high, can be noted as well. And that was against the background of the large-scale standard development, altitude range of which increased from the beginning of the $18^{\text {th }}$ century to the beginning of the $20^{\text {th }}$ century from 7-10 $\mathrm{m}$ to $24-30$ $\mathrm{m}$. Since the 1930s, a new tradition for the arrangement of high-rise dominants (with a height of up to $12-130 \mathrm{~m}$ ) formed in the urban planning of Leningrad. Thus, high-rise construction, occurred in the Saint Petersburg region as far back as in the 1710s, solved tasks of forming the single visual urban-planning space.

\section{References}

1. Edict "On the Construction of Houses in Saint Petersburg" signed by the Tsar on November 4 (15), 1714. Complete collection of laws of the Russian Empire, first collection, 2855, Saint Petersburg, 128 (1830).

2. S. V. Sementsov, Traditions of Peter the Great in the formation of the permanent Saint Petersburg agglomeration in the $18^{\text {th }}$ century. Faces of Petrine times - 2011. To the commemoration of the 30th anniversary of the Menshikov Palace department of the State Hermitage (1981-2011). Proc. of the scientific conf., 329-341 (2011)

3. S. V. Sementsov, Krasnikova O. A., Mazur T. P., Shrader T. A. Saint Petersburg on maps and plans of the first half of the $18^{\text {th }}$ century, 436 (2004).

4. PLAN OF THE CITY OF SAINT PETERSBURG compiled in the General Headquarters of HIS IMPERIAL MAJESTY by Major General I. Vitztum AND ENGRAVED IN THE MILITARY TOPOGRAPHICAL DEPOT. 1821 / PLAN DE LA VILLE DE St. PETERSBOURG Composé à l'Etat-Maior de SA MAJESTÈ L' EMPEREUR par le Général-Major de Vitzthum, ET GRAVÈ AU DEPOT TOPOGRAPHIQUE MILITAIRE. Saint Petersburg. RNb K1-Pb 6/72 (1821).

5. B. A. Rozadeyev, R. A. Somina, L. S. Klescheva, Kronstadt, 144 (1977).

6. N. A. Akulova, Stages of urban-planning development in the city of Kronstadt in the $19^{\text {th }}$ century. Bulletin of Civil Engineers, 4 (33), 5-8 (2012).

7. S. V. Krylova, Architectural-spatial and compositional features of the arrangement of temples in Saint Petersburg and surrounding districts (uyezds) in the $18^{\text {th }}$ - first half of the $19^{\text {th }}$ centuries. Moscow Bulletin of Engineers, 3 (28), 15-22 (2013).

8. S. V. Sementsov, Development of the revolutionary architectural avant-garde in Petrograd-Leningrad according to urban-planning standards of the Imperial Saint Petersburg. Part 1: from Peter the Great to V. I. Lenin. Vestnik of Saint Petersburg University. Arts, 7 (2), 249-272. (2017).

9. N. N. Punin The Monument to the Third International. Project by artist V. Ye. Tatlin, 1$8(1920)$.

10. N. A. Semashko (ed.). The Great Leader: art and literary collection, (1924).

11. About the monument to Lenin, 112 (1924)

12. Competitive design of the lighthouse-monument to V. I. Lenin in the Leningrad port, executed on behalf of the Society of Architectural Artists by Langbard I. G. Annual publication of the Society of Architectural Artists, 14, 281 (1935).

13. N. N. Baranov, V. G. Isachenko Chief architect of Leningrad Nikolay Baranov: career and destiny, 127 (2001).

14. Architecture and construction of Leningrad. Collection 13, 11 (1950).

15. Architecture and construction of Leningrad. Collection 15, 11 (1951). 
16. Architecture and construction of Leningrad. Collection 17, 10 (1952).

17. Imperial regulation of the Committee of Ministers, issued by the Minister of Internal Affairs, September 2, 1847 Complete collection of laws of the Russian Empire, second collection, 22 (1), No. 21.515, 699-700 (1847).

18. S. V. Sementsov, Ranks of detalization and zones of medieval Novgorod architecture perception. Aesthetic problems of Soviet architecture. Inter-university collected works, 117-124 (1979).

19. S. V. Krylova, Silhouette and visual interrelations of temples in Saint Petersburg and its suburbs in 1800-1835. Challenging Issues of Modern Construction. Proc. of the Int. Scientific and Practical Conf. of Students, PhD Students, Young Scientists and Second Doctorate Students. 1, 156-159 (2012).

20. N. Akulova, Y. Voznyak, Y. Ardasheva, History of Holy Trinity Church in Pyataya Gora homestead of Tsarskoselsky County and choice of method of its restoration. Architecture and Engineering, 1 (3), 3-13 (2016). 